\title{
Co-presence of human papillomaviruses and Epstein-Barr virus is linked with advanced tumor stage: a tissue microarray study in head and neck cancer patients
}

Hamda Al-Thawadi ${ }^{1 \dagger}$, Ishita Gupta $^{1+} \mathbb{0}$, Ayesha Jabeen ${ }^{1}$, Faruk Skenderi ${ }^{2}$, Tahar Aboulkassim ${ }^{3}$, Amber Yasmeen $^{3}$, Mohammed I. Malki ${ }^{1}$, Gerald Batist ${ }^{3,4}$, Semir Vranic ${ }^{1 *}$ (D) and Ala-Eddin Al Moustafa ${ }^{1,4^{*}}$ (D)

\begin{abstract}
Background: Human papillomaviruses (HPVs) and Epstein-Barr virus (EBV), known oncoviruses, can be co-present and cooperate in the initiation and/or progression of human carcinomas, including head and neck. Based on this fact, we recently reported the prevalence of both HPVs and EBV in cervical and breast cancers.

Methods: We herein explore for the first time the co-prevalence of high-risk HPVs and EBV in 98 head and neck (HN) squamous cell carcinoma (SCC) tissues from Bosnian patients using polymerase chain reaction (PCR) and immunohistochemistry $(\mathrm{IHC})$ analysis, as well as tissue microarray methodology.

Results: The majority of these cancer tissue cases were from the oral cavity (68\%). We found that high-risk HPVs and EBV are co-present in $34.7 \%$ of the SCC samples; with a significant correlation between the various HPV types and EBV co-incidence $(p=0.03)$. Our data showed that $30.8 \%$ of oral SCCs are positive for E6 oncoprotein of high-risk HPVs and $44.6 \%$ are positive for LMP1 of EBV. The most commonly expressed HPVs in our HNSCC samples include HPV types 16, 18,45 and 58 . Additionally, $37.5 \%$ of oral SCCs are positive for both HPVs and EBV, with statistically significant association between high-risk HPV types and EBV $(p<0.05)$. More importantly, our data revealed that the co-presence of HPV and EBV is strongly correlated with advanced tumor stage $(p=0.035)$.

Conclusion: In this study we show that HPV and EBV oncoviruses are co-present in HNSCC, particularly in oral cancer, where they can cooperate in the initiation and/or progression of this cancer. Thus, further studies are necessary to elucidate the mechanism of this cooperation.
\end{abstract}

Keywords: Epstein-Barr virus, Human papillomaviruses, Oral cancer, Head and neck cancer, Bosnian population

\section{Introduction}

Head and neck $(\mathrm{HN})$ cancers are a group of malignant neoplasms arising from the oral cavity, craniofacial

\footnotetext{
*Correspondence: svranic@qu.edu.qa; aalmoustafa@qu.edu.qa; ala-eddin. almoustafa@mcgill.ca

${ }^{\dagger}$ Hamda Al-Thawadi and Ishita Gupta contributed equally to this work ${ }^{1}$ College of Medicine, QU Health, Qatar University, P. O. Box 2713, Doha, Qatar

Full list of author information is available at the end of the article
}

bones, nose, larynx, pharynx as well as the salivary glands [1]. These cancers are the tenth most frequently occurring cancer worldwide [2] comprising of $5-50 \%$ of all cancers [3]. The majority of the HN cancers originate from the epithelium lining of the oral cavity, pharynx and larynx, indicating squamous differentiation [1]. Histologically, squamous cell carcinoma (SCC) constitute most tumors found in the head and neck region $(\sim 90 \%)[1,4]$ followed by other histological types such as lymphomas,

(c) The Author(s) 2020. This article is licensed under a Creative Commons Attribution 4.0 International License, which permits use, sharing, adaptation, distribution and reproduction in any medium or format, as long as you give appropriate credit to the original author(s) and the source, provide a link to the Creative Commons licence, and indicate if changes were made. The images or other third party material in this article are included in the article's Creative Commons licence, unless indicated otherwise in a credit line to the material. If material is not included in the article's Creative Commons licence and your intended use is not permitted by statutory regulation or exceeds the permitted use, you will need to obtain permission directly from the copyright holder. To view a copy of this licence, visit http://creativeco mmons.org/licenses/by/4.0/. The Creative Commons Public Domain Dedication waiver (http://creativecommons.org/publicdomain/ zero/1.0/) applies to the data made available in this article, unless otherwise stated in a credit line to the data. 
sarcomas or blastomas [4]. The main features of this disease include late diagnosis, high mortality rates and morbidity $[5,6]$.

Tobacco consumption is the primary known cause of $\mathrm{HN}$ cancers including oral [5] followed by viral infections by high-risk human papillomaviruses (HPVs) and Epstein-Barr virus (EBV) that are associated with the development and/or progression of head and neck $(\mathrm{HN})$ carcinomas [7-9].

Human papillomaviruses (HPVs) are human oncoviruses that are sexually transmitted and are strongly associated with cervical carcinomas [10]. HPVs are small, double-stranded DNA viruses which tend to infect cutaneous and mucosal epithelial tissues of the ano-genital tract [11]. HPVs are categorized into high-risk or lowrisk, with high-risk types duly linked with the onset and progression of cancer [10, 12]. While, low-risk HPV subtypes induce multiplication of epithelial cells that develop into warts or skin papillomas [13, 14]. Earlier investigations indicated that persistent infection with high-risk HPVs is critical for the development of invasive carcinomas $[10,15]$. Moreover, it was pointed out that their presence is linked with tumor size, vascular invasion and lymph node metastases [16-20]; which makes them a useful prognostic factor in early-stage cervical, $\mathrm{HN}$, and colorectal carcinomas. In addition, it has been pointed out that E6/E7 oncoproteins of high-risk HPVs convert non-invasive and non-metastatic cancer cells into invasive and metastatic form [21].

On the other hand, Epstein-Barr virus (EBV), a human DNA oncogenic gamma-1 herpesvirus affects around 90\% of adults [22]. During EBV infection, cells express six EBV nuclear proteins (EBNA1, -2, -3A, -3B, -3C, and $-\mathrm{LP}$ ), three latent membrane proteins (LMP1, $-2 \mathrm{~A}$, and $-2 \mathrm{~B}$ ), and multiple non-coding RNAs (EBERs and miRNAs) [23-25]. EBV virus is associated with a broad spectrum of diseases including multiple sclerosis (MS), infectious mononucleosis (glandular fever) and it has the potential to transform B lymphocytes which causes various malignancies, including lymphoid. Additionally, EBV infection is linked with several types of epithelial carcinomas [26]. While, all cases of undifferentiated nasopharyngeal carcinoma are EBV-associated [27], in gastric cancer EBV is present only in a subset of gastric cancers $[28,29]$. However, in breast and cervical cancers, the role of EBV is controversial; while a few studies have detected EBV presence in these cancers [30-34], other studies failed to detect it [35-39].

EBV's key oncogenic protein LMP1 induces cell growth, decreases apoptosis, promotes cell motility and angiogenesis and is also known to express frequently in human oral cancer [40, 41]. Moreover, various EBV genes including latent genes contribute to transformation of human B and some oral epithelial cells and are continually expressed in EBV-associated cancer cells, which links EBV with viral oncogenesis [42-44]; for example, expression of EBNA1, LMP1, -2A genes characterize type II latency and is linked with Hodgkin's lymphoma and some carcinomas like gastric, nasopharyngeal and breast [22, 26].

Accumulating evidence show that infection with at least one type of high-risk HPV alone is not sufficient to induce neoplastic transformation; high-risk HPVinfected cells must undergo further genetic changes and/ or co-infection with another oncovirus to attain complete cellular transformation and consequently tumor development [31, 32, 42, 45-48]. Hence, in this study, we explored the co-presence of high-risk HPVs and EBV in $\mathrm{HN}$ cancer samples from Bosnian patients. Our study pointed out that EBV and HPVs are co-present in 34.7\% of our samples, and their co-presence is associated with advanced tumor stage.

\section{Materials and methods \\ Sample collection and ethical approval}

All samples were taken from formalin-fixed paraffinembedded (FFPE) tissues from surgically removed and pathologically confirmed squamous cell carcinomas of the head and neck. The samples were retrieved, and approved to be used for research, from the pathology archive of the Department of Pathology, Clinical Center, University of Sarajevo. All samples for the study were de-identified, therefore the patient consent was not needed per local protocol. Only cases having at least one redundant FFPE block were used in the study. The Qatar University Institutional Biosafety Committee (IBC) and Institutional Review Board (IRB) committees approved the project (Numbers: QU-IBC-2018/064 and APP$16 / 05 / 2018 / G C C)$. The study was performed in accordance with relevant guidelines and regulations of these committees at Qatar University.

Prior to molecular assays, all hematoxylin and eosin (H\&E) slides were re-reviewed by board-certified pathologists (Drs. Semir Vranic and Faruk Skenderi) to confirm the diagnosis and select appropriate samples for tissue microarray and molecular assays (PCR and IHC).

\section{DNA extraction}

DNA extraction from FFPE tissues was performed using Qiagen AllPrep DNA/RNA FFPE Kit (Qiagen, Ltd., Crawley, UK). Briefly, aliquots of $200 \mu \mathrm{l}$ of samples were digested with $20 \mu \mathrm{l}$ of $\mathrm{K}$ proteinase and $200 \mu \mathrm{l}$ of $\mathrm{AL}$ buffer at $56{ }^{\circ} \mathrm{C}$, for $10 \mathrm{~min}$. DNA precipitation was performed by adding $200 \mu \mathrm{l}$ of $96 \%$ ethanol. DNA was eluted in $200 \mu \mathrm{l}$ of $\mathrm{AE}$ buffer and stored at $-20{ }^{\circ} \mathrm{C}$ until further 
use. The samples collection and DNA extraction were achieved as previously illustrated $[49,50]$.

\section{HPV and EBV detection}

Twenty-five nanograms of purified genomic DNA from each sample was analyzed for EBV and HPV by polymerase chain reaction (PCR) as previously described [51] using specific primers for LMP1 as well as E6/E7 of HPV types: 16, 18, 31, 33, 35, 45, 51, 52 and 58. MY09/MY11 and GP5 +/GP6 + primers were also used to amplify the L1 region of the viral genome which is commonly used for HPV detection in clinical and histological studies [52]. GAPDH primers (Forward Primer: 5'-GAAGGC -CATGCCAGTGAGCT-3' and Reverse Primer: $5^{\prime}$-CCG GGAAACTGTGGCGTGAT-3') were used as an internal control. Primers and analysis was performed as previously described by our group $[49,50]$.

Briefly, LMP1 gene (Forward Primer: 5'-TTGGAGATT CTCTGGCGACT- $3^{\prime}$ and Reverse Primer: $5^{\prime}$-AGTCAT CGTGGTGGTGTTCA-3') was amplified for an initial denaturation at $95{ }^{\circ} \mathrm{C}$ for 10 min followed by 40 cycles of $95{ }^{\circ} \mathrm{C}$ for $30 \mathrm{~s}, 61{ }^{\circ} \mathrm{C}$ for $1 \mathrm{~min}$, and $72{ }^{\circ} \mathrm{C}$ for $1 \mathrm{~min}$. In parallel, HPV gene was amplified for an initial denaturation at $95^{\circ} \mathrm{C}$ for $10 \mathrm{~min}$ followed by 40 cycles of $95^{\circ} \mathrm{C}$ for $30 \mathrm{~s}$, annealing at temperatures ranging from 50 to $62^{\circ} \mathrm{C}$ for 1 min depending on each primer's melting temperature as previously described [49], and $72{ }^{\circ} \mathrm{C}$ for $1 \mathrm{~min}$. Samples were finally incubated for $10 \mathrm{~min}$ at $72{ }^{\circ} \mathrm{C}$ for a final extension. The PCR product from each exon was resolved by using $1.5 \%$ agarose gel electrophoresis.

In each experiment, a negative control (sterile water instead of DNA) and a positive control (such as Hela and Siha cell lines) were used.

\section{Tissue microarray (TMA)}

Tissue microarray construction was attained as described previously by our group [31, 32, 53]. Briefly, cancer samples and controls were embedded into a virgin paraffin TMA block using a manual tissue arrayer (Beecher Instruments, Silver Spring, MD, USA). All FFPE samples were de-identified and assembled without any previous knowledge of linked clinical or pathological staging information.

Two TMA cores of $1.0 \mathrm{~mm}$ in diameter were sampled from a cohort of 98 FFPE samples from Bosnian patients with confirmed oral squamous cell carcinoma. Later, sections of $4 \mu \mathrm{m}$ were cut and stained with hematoxylin and eosin on the initial slides to verify the histopathologic diagnosis (cancer tissues). Next, slides of the completed blocks were used for immunohistochemistry (IHC) assays (against E6 and LMP1 of high-risk HPV and EBV, respectively).

\section{Immunohistochemistry (IHC)}

Immunohistochemical analysis investigating the expression of E6 of HPV and LMP1 of EBV were performed using procedures as previously described [53]. To analyze protein expression patterns of E6 and LMP1 in TMA slides, each slide was deparaffinized in graded alcohol, rehydrated and boiled (microwave) in $10 \mathrm{mM}$ citrate sodium citrate solution $(\mathrm{pH} 6.0)$ for $10 \mathrm{~min}$. Endogenous peroxidase activity within the rehydrated tissue was blocked with a solution of $3 \%$ hydrogen peroxide in methanol for $10 \mathrm{~min}$ at room temperature. TMA slides were further incubated for $35 \mathrm{~min}$ at $37^{\circ} \mathrm{C}$ with primary monoclonal antibodies for E6 of HPV (clones 1-4 and C1P5, Dako Agilent, Carpinteria, CA and Calbiochem, Canada) and LMP1 of EBV using a fully automated immunostainer (Ventana Medical System, Tuscon, AZ). The fully automated Ventana Medical System uses an indirect biotin-avidin system with a universal biotinylated immunoglobulin secondary antibody. The slides were counterstained with hematoxylin prior to mounting. The staining procedures were completed according to the manufacturer's recommendations. Negative controls were obtained by omitting specific primary antibody for E6 and LMP1 as well as specific blocking peptides from Santa Cruz Biotechnology.

The tumors were considered positive for E6 and LMP1 if cancer cells exhibited positivity $\geq 1 \%$ of the cells [32]. In case of LMP1 protein expression (EBV), we also evaluated the presence of viral infection in tumor-infiltrating lymphocytes and stromal cells [32].

\section{Statistical analysis}

Statistical analysis was performed using IBM Statistical Package for the Social Sciences (version 25) and R. Data were calculated as non-parametric files. Spearman Correlation Rank test was used to assess the significance of HPV and EBV association. We utilized $\chi^{2}$ test with Yates correction to assess the significance of the association between clinicopathological data (patient's age, cancer grade and tumor stage) and the co-presence of HPVs and EBV. Statistical significance was achieved at $p<0.05$.

\section{Results}

\section{Clinicopathological characteristics of the cohort}

The cohort of head and neck carcinomas included 123 cases and 17 squamous cell carcinomas from other anatomic locations (skin, cervix and esophagus) making a total of 140 cases. After careful assessment, ninety-eight cases had available FFPE blocks for TMA and PCR.

The mean age of patients was 62.8 years (range, 24-91 years), the majority of them were male $(72.8 \%)$ (Table 1). All cancers in the study are histologically 
squamous cell carcinomas (SCC). The study included cancers originating from the oral cavity $(66.4 \%)$ followed by cancer of the larynx (17.9\%). Cancers of the pharynx and other anatomic locations (skin, cervix) were rare and comprised only of $3.6 \%$ and $10.7 \%$ of the cases, respectively (Table 1).

Of the studied cases, there are twenty-four well-differentiated carcinomas cases (17.1\%) (G1), 85 moderately differentiated (60.7\%) (G2) and 16 poorly differentiated (11.4\%) (G3) (Table 1; Figs. 1a, b, 2a, b, 3a, b, 4a, b). Based on the tumor stage, 41 (29.3\%) cases are stage 1, $39(27.9 \%)$ cases are stage 2, while, $21(15 \%)$ cases are reported to have stage 3 and $30(21.4 \%)$ cases are stage 4 (Table 1).

\section{Presence of high-risk HPV subtypes and EBV by PCR}

Ninety-eight SCC samples had interpretable results for HPV and EBV by PCR (Additional files 1, 2: Figures S1 and S2).

It revealed that $55(56.1 \%)$ of the samples are positive for E6 of high-risk HPVs and 68 (69.3\%) of the samples are positive for LMP1 of EBV. Out of ninety-eight SCC samples, 34 (34.7\%) are positive for both HPVs and EBV (Table 2). In addition, there is a significant correlation between the coincidence of EBV with various HPV types [HPV $16(\mathrm{p}=0.03), \operatorname{HPV} 18(\mathrm{p}=0.003), \operatorname{HPV} 45(\mathrm{p}=0.04)$, HPV58 $(\mathrm{p}=0.02)]$ in HNSCC samples (Table 2$)$.

Our data showed that, the most commonly expressed high-risk HPVs in Bosnian HNSCC samples are HPV18

Table 1 Clinicopathological characteristics of the cohort of the patients with squamous cell carcinoma (oral cavity and other locations)

\begin{tabular}{|c|c|c|}
\hline Characteristic & Categories & Number (\%) \\
\hline \multirow[t]{2}{*}{ Gender } & Male & $102(72.8)$ \\
\hline & Female & $38(27.1)$ \\
\hline \multirow[t]{5}{*}{ Squamous cell carcinoma histology (by anatomic location) } & Oral cavity & $93(66.4)$ \\
\hline & Larynx & $25(17.9)$ \\
\hline & Pharynx & $5(3.6)$ \\
\hline & Other locations (skin, cervix) & $15(10.7)$ \\
\hline & Unknown & $2(1.4)$ \\
\hline \multirow[t]{4}{*}{ Cancer grade } & G1 & $24(17.1)$ \\
\hline & G2 & $85(60.7)$ \\
\hline & G3 & $16(11.4)$ \\
\hline & Unknown & $15(10.7)$ \\
\hline \multirow[t]{5}{*}{ Tumor ( $\mathrm{pT}$ ) stage } & pT1 & $41(29.3)$ \\
\hline & pT2 & $39(27.9)$ \\
\hline & pT3 & $21(15.0)$ \\
\hline & pT4 & $30(21.4)$ \\
\hline & Unknown & $9(6.4)$ \\
\hline \multirow[t]{4}{*}{ HPV (E6) oncoprotein expression (IHC) } & Oral cavity & $21(44.6)$ \\
\hline & Larynx & $14(87.5)$ \\
\hline & Pharynx & $4(80)$ \\
\hline & Other locations (skin, cervix) & $1(16.6)$ \\
\hline \multirow[t]{4}{*}{ EBV (LMP1) oncoprotein expression (IHC) } & Oral cavity & $35(76)$ \\
\hline & Larynx & $1(33.3)$ \\
\hline & Pharynx & $3(100)$ \\
\hline & Other locations (skin, cervix) & $2(40)$ \\
\hline \multirow[t]{4}{*}{ HPV (E6) oncoprotein expression (PCR) } & Oral cavity & $29(45.3)$ \\
\hline & Larynx & $17(70.8)$ \\
\hline & Pharynx & $3(60)$ \\
\hline & Other locations (skin, cervix) & $3(60)$ \\
\hline \multirow[t]{4}{*}{ EBV (LMP1) oncoprotein expression (PCR) } & Oral cavity & $50(78.1)$ \\
\hline & Larynx & $14(21.8)$ \\
\hline & Pharynx & $1(4.1)$ \\
\hline & Other locations (skin, cervix) & $3(60)$ \\
\hline
\end{tabular}



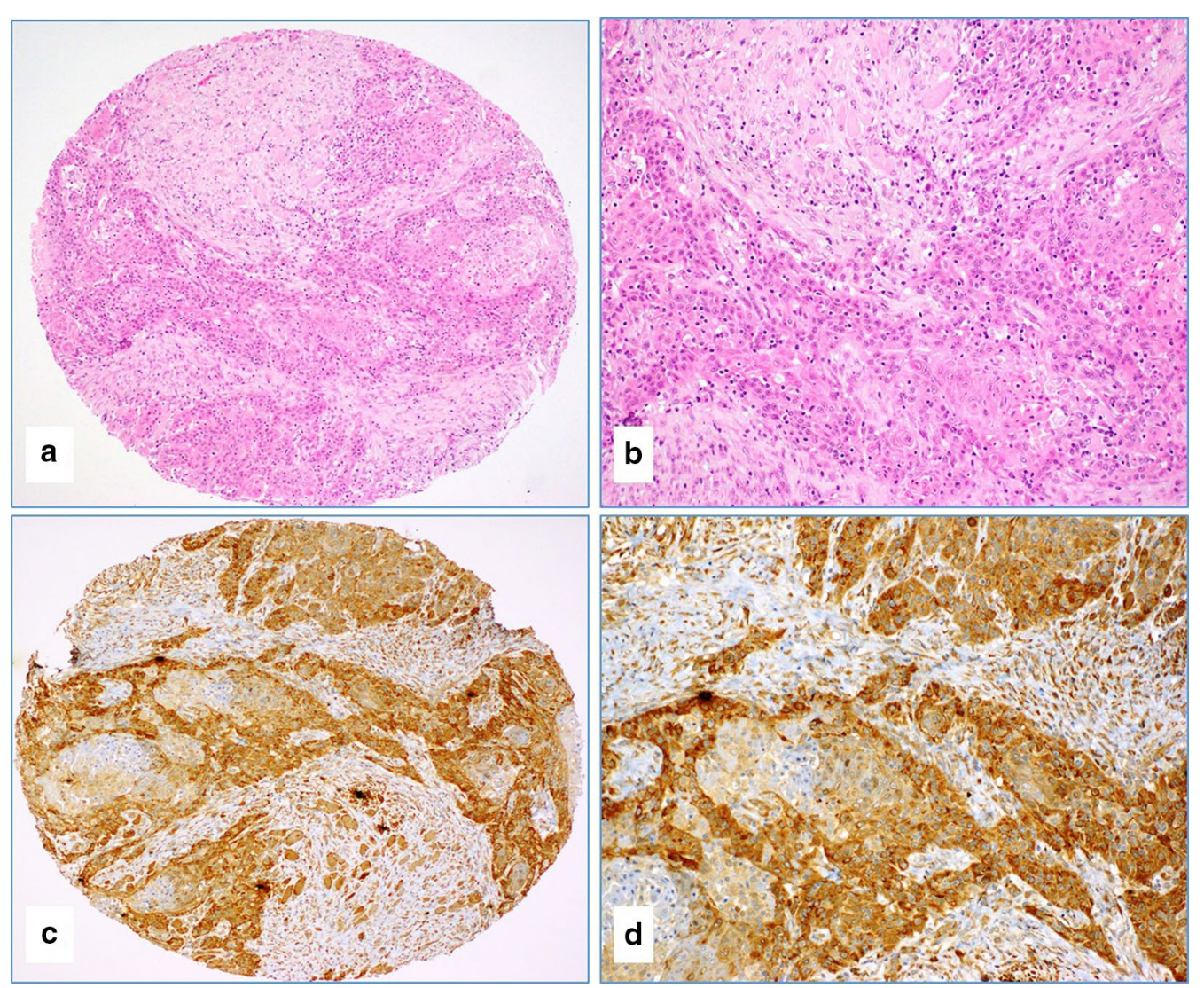

Fig. 1 a-d The case of moderately differentiated (G2) oral squamous cell carcinoma (a, b Hematoxylin and Eosin staining) with a diffuse and strong expression of E6 protein of HPV by immunohistochemistry (a and $\mathbf{c}$ figures, $\times 4$ magnifications; $\mathbf{b}$ and $\mathbf{d}$ figures, $\times 20$ magnifications)
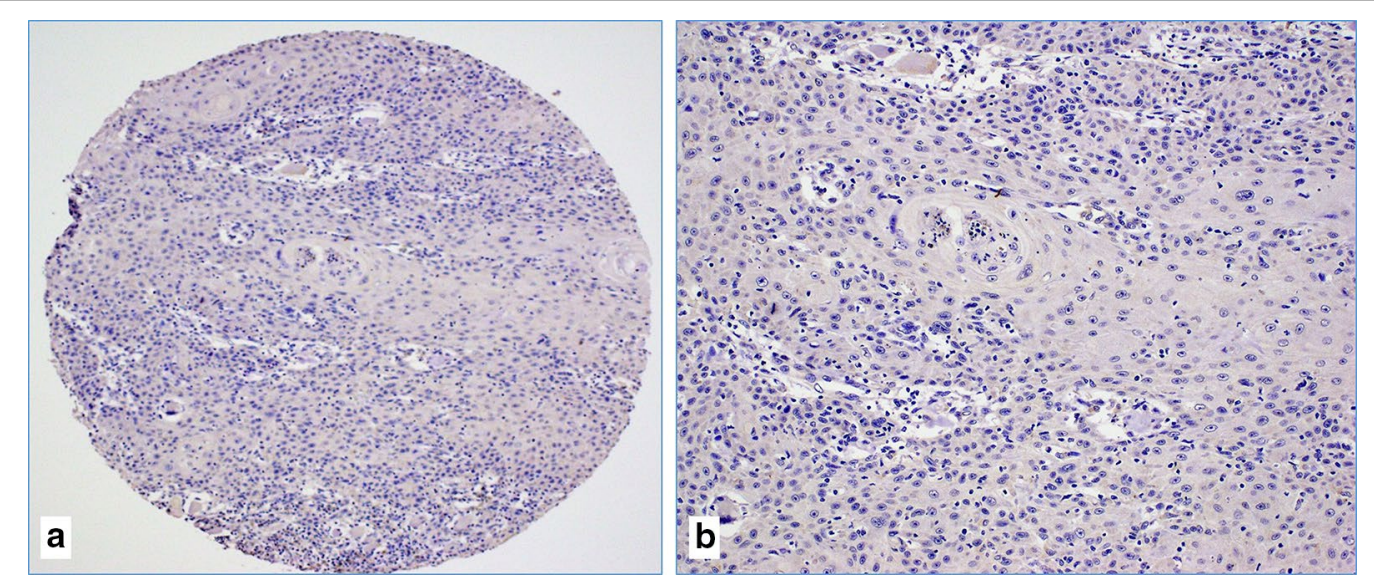

Fig. 2 a, b The case of moderately differentiated (G2) squamous cell carcinoma with negative IHC reaction against E6 of HPV (image A at $\times 10$ magnification and image $B$ at $\times 20$ magnification)

(56\%) followed by HPV58 (48\%), HPV45 (27\%), HPV16 (21\%), HPV52 (14\%), HPV31 and HPV51 (9.2\% each) and HPV 35 (3\%) (Fig. 5). Moreover, 13 (13.2\%) of the 98 samples are co-infected with both HPV16 and 18 (Fig. 6).
Moreover, the Bosnian HNSCC cancers were coinfected with more than one type of HPV in 49 out of 98 samples (50\%). Figure 6 shows the most common 

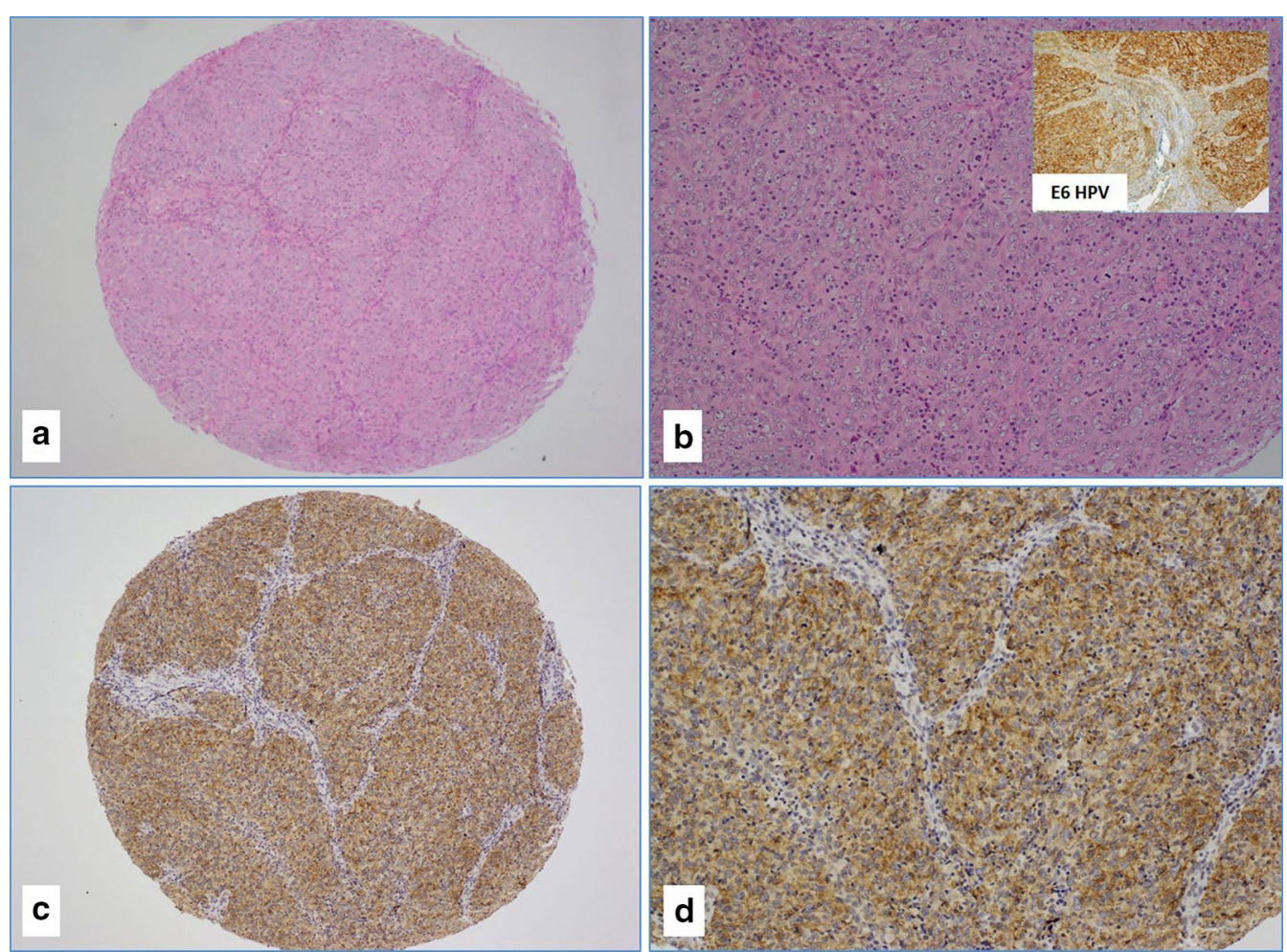

Fig. 3 a-d The case of poorly differentiated (G3) oral squamous cell carcinoma ( $\mathbf{a}, \mathbf{b}$ Hematoxylin and Eosin staining) that was diffusely and strongly positive for LMP1 protein of EBV $(\mathbf{c}, \mathbf{d})$; This cancer also strongly co-expressed E6 protein of HPV (the image in the right upper corner of $\mathbf{b})(\mathbf{a}-\mathbf{c} \times 4$ magnifications; $\mathbf{b}-\mathbf{d} \times 20$ magnifications)
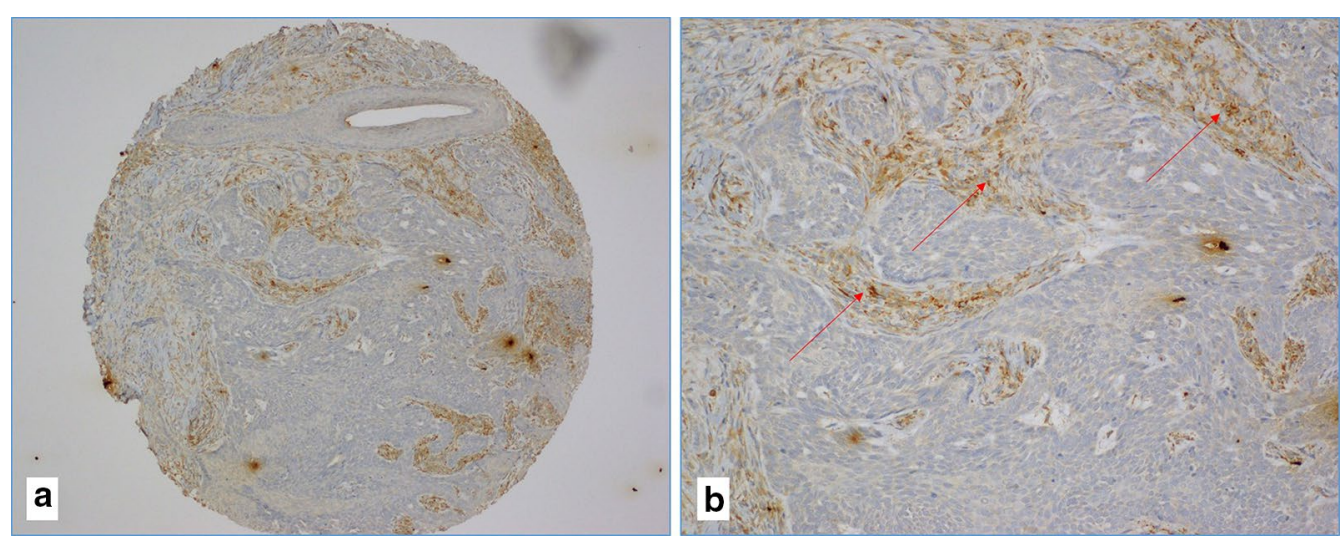

Fig. 4 a, b The case of poorly differentiated (G3) squamous cell carcinoma with negative IHC reaction against LMP1 of EBV (image $\mathbf{a}$ at $\times 10$ magnification and image $\mathbf{b}$ at $\times 20$ magnification). The red arrows in image B indicate the positive reaction of LMP1 in tumor-infiltrating lymphocytes

co-infections of HNSCC samples with HPV18 and other high-risk HPV subtypes.

Regarding the anatomical distribution of these oncoviruses, out of the 98 cases, anatomical location was available for 94 cases. Thus, twenty-nine of the sixty-four oral
SCC samples (45.3\%) were positive for E6 of high-risk HPVs and 50 (78.1\%) of them were positive for LMP1 of EBV. On the other hand, 37.5\% of oral SCC samples were positive for both HPVs and EBV. In addition, in oral cancer samples, a significant association was observed 
Table 2 Prevalence of high-risk HPV types in relation to EBV status in HNSCC cohort $(n=98)$

\begin{tabular}{|c|c|c|c|c|c|c|c|c|c|c|}
\hline \multirow[t]{2}{*}{ Samples } & \multirow[t]{2}{*}{ No. of cases } & \multicolumn{9}{|c|}{ High-risk HPV types } \\
\hline & & 16 & 18 & 31 & 33 & 35 & 45 & 51 & 52 & 58 \\
\hline $\operatorname{EBV}(+)$ & 68 & 10 & 31 & 8 & 0 & 0 & 20 & 7 & 10 & 27 \\
\hline $\operatorname{EBV}(-)$ & 30 & 11 & 24 & 1 & 0 & 3 & 7 & 2 & 4 & 20 \\
\hline Total & 98 & 21 & 55 & 9 & 0 & 3 & 27 & 9 & 14 & 47 \\
\hline$p$-value & & $0.03^{*}$ & $0.003^{* *}$ & 0.34 & $\mathrm{~N} / \mathrm{A}$ & $\mathrm{N} / \mathrm{A}$ & $0.04^{*}$ & 0.85 & 0.89 & $0.02^{*}$ \\
\hline
\end{tabular}

Significant $p$-values are denoted by asterisk $(*)$

\section{Distribution of Separate High-Risk HPV Subtypes between the analyzed HNSCC tissue samples}

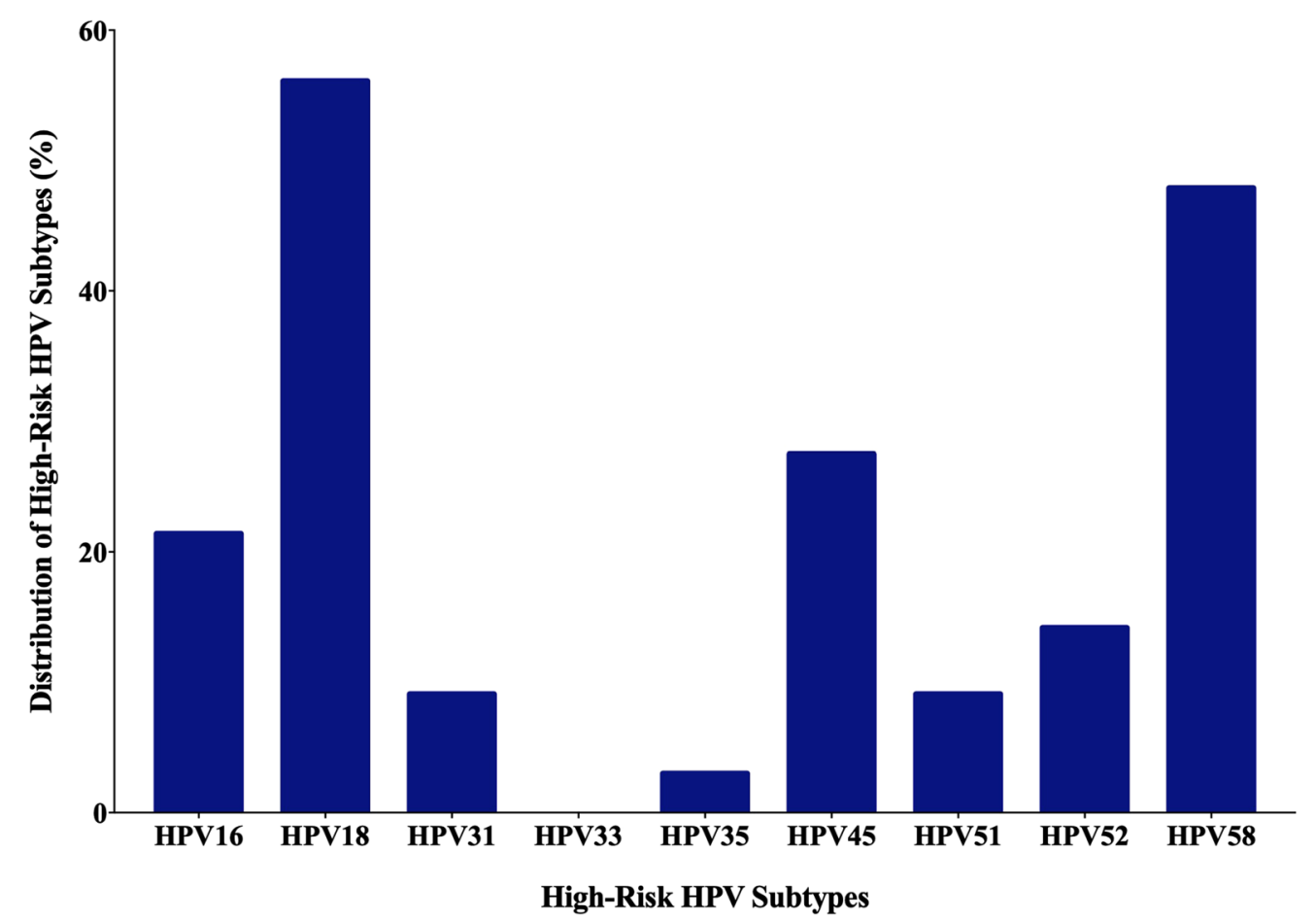

Fig. 5 The distribution of each high-risk HPV subtype by PCR according to the frequency in the HNSCC cohort ( $\mathrm{n}=98$ )

between EBV and several high-risk HPV types [HPV-16 $(\mathrm{p}=0.000), H P V-18 \quad(\mathrm{p}=0.0005), H P V-31 \quad(\mathrm{p}=0.000)$, HPV-35 ( $\mathrm{p}=0), \operatorname{HPV}-45(\mathrm{p}=0.006), \operatorname{HPV}-51(\mathrm{p}=0.000)$, HPV $-58(\mathrm{p}=0.02)]$.

\section{Expression patterns of E6 and LMP1 of high-risk HPVs and EBV}

Seventy-nine samples were used for IHC to detect high-risk HPV E6. The remaining 19 cases were not interpretable due to sparsity of cancer tissue in the TMA cores. The frequency of E6 of HPV positivity in these samples by IHC was $57 \%$ (45/79), which is in agreement with the PCR data, where 56.1\% (55/98) of SCC samples were positive for E6 of HPV (Table 2). Thirteen cases (16.5\%) exhibited diffused (90-100\%) and strong HPV E6 protein expression in cancer cells (Fig. 1c, d) while ten cases (12.6\%) had low HPV E6 expression (1-25\% positive cancer cells). The positivity of E6 oncoprotein of high-risk HPV was predominantly observed in cancer cells (Fig. 1c, d). It was both cytoplasmic and nuclear. Rarely, high-risk HPV E6 oncoprotein expression was noted in cancer stroma (fibroblasts and inflammatory cells) (Fig. 1c, d). The remaining 34 cases were negative for E6 of HPV (Fig. 2). 


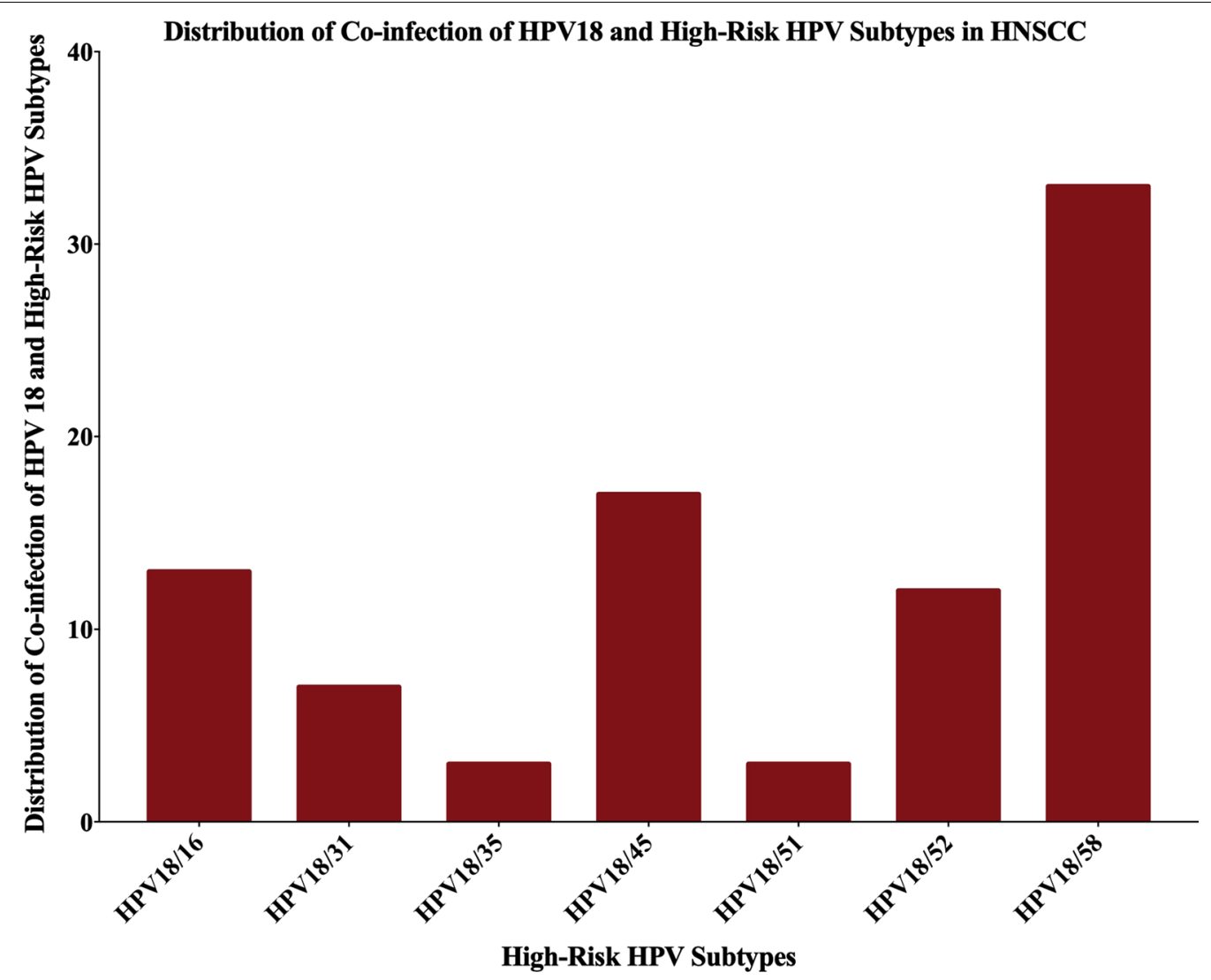

Fig. 6 The distribution of co-infection of HPV18 with other high-risk HPV subtypes in HNSCC. The most commonly co-infected subtype was HPV18/58 (33/98; 33.7\%) followed by HPV18/45 (17/98; 17.3\%), HPV18/16 (13/98; 13.2\%), HPV 18/52 (12/98; 12.2\%), HPV18/31 (7/98; 7.1\%), HPV18/35 and HPV16/51 (3/98; 3.1\% each). Since, HPV33 was not present in the cohort, there was no co-expression for HPV18 with these subtypes

Additionally, using IHC we found that the expression of E6 of high-risk HPV was detected highly in the larynx $(87.5 \%)$ and pharynx $(80 \%)$ followed by the oral cavity (44.6\%) (Table 1); Results are comparable to PCR data, where HPV was highly expressed in the larynx (70.8\%) and pharynx $(60 \%)$ followed by the oral cavity (45.3\%) (Table 1).

LMP1 oncoprotein of EBV was available for 68 cases, as nine cases were not assessable due to sparse or complete absence of cancer tissue. LMP1 was positive in 42 (71\%) of the 59 cases which also correlated with EBV PCR data (positivity 69.3\%). The mean percentage of LMP1 protein in cancer cells was 46\% (range, 0-95\%) (Fig. 3c, d). LMP1 was predominantly cytoplasmic and membranous (Fig. 3c, d). No nuclear expression was observed in any of the tested cases. LMP1 protein was occasionally positive in cancer stroma (lymphocytes) (Fig. 4a, b) as well as in immune cells (lymphocytes) of the TMA cores that contained no cancer tissues but normal tissue with some inflammatory cells (data not shown).

LMP1 was also highly expressed in the pharynx (100\%) followed by oral cavity (76\%) and larynx (33.3\%) (Table 1).
Seventeen of the 57 samples $(29.8 \%)$ were positive ( $\geq 1 \%$ positive cancer cells) for both EBV and HPVs in SCC (Fig. 3b); nevertheless, in our PCR data, co-incidence in SCC samples was $34.7 \%$. Seven cases were both HPV and EBV negative. In addition, we found statistically significant association between various HPV types and EBV co-infection $(\mathrm{p}=0.03)$ in SCC; this data is in concordance with our PCR data.

\section{Correlation of clinicopathological characteristics with HPV/ EBV positivity}

HPV positivity correlated strongly with tumor grade $(\mathrm{p}=0.02)$, tumor stage $(\mathrm{pT})(\mathrm{p}<0.001)$ and advanced $\mathrm{pN}$ stage $(\mathrm{p}=0.045)$ (Table 3$)$. On the other hand, EBV positivity had no significant association with tumor grade $(\mathrm{p}=0.47)$, tumor stage $(\mathrm{p}=0.53)$ and $\mathrm{pN}$ stage $(\mathrm{p}=0.14)$ (Table 3).

More significantly, we found that the co-expression of LMP1 of EBV and E6 of high-risk HPVs $(\mathrm{EBV}+/ \mathrm{HPV}+)$ is associated with advanced tumor stage $(p=0.035)$ (Table 4); nevertheless, no positive association was found with tumor grade $(\mathrm{p}=0.4)$ (Fig. $3 \mathrm{~b})$. 
Table 3 Correlation of clinicopathological characteristics with HPV presence

\begin{tabular}{lccc}
\hline Degree of differentiation & $\begin{array}{l}\text { HPV (E6) } \\
\text { positive (\%) }\end{array}$ & $\begin{array}{l}\text { HPV (E6) } \\
\text { negative (\%) }\end{array}$ & p-value \\
\hline Tumor grade & & & \\
Well-differentiated & $6(8.6)$ & $9(13)$ & $\mathrm{p}=0.02^{*}$ \\
Moderately-differentiated & $23(33.3)$ & $20(28.9)$ & \\
Poorly-differentiated & $10(14.4)$ & $1(1.4)$ & \\
Total & $39(56.5)$ & $30(43.4)$ & \\
Tumor Stage (pT) & & & \\
pT1 & $3(4.4)$ & $14(20.8)$ & $\mathrm{p}<0.001^{*}$ \\
pT2 & $10(14.9)$ & $12(17.9)$ & \\
pT3 & $13(19.4)$ & $2(2.9)$ & \\
pT4 & $10(14.9)$ & $3(4.4)$ & \\
Total & $36(53.7)$ & $31(46.2)$ & \\
pN Stage & & & \\
pN0 & $11(29.7)$ & $8(21.6)$ & $\mathrm{p}=0.045^{*}$ \\
pN1 & $8(21.6)$ & $2(5.4)$ & \\
pN2 & $7(18.9)$ & $1(2.7)$ & \\
Total & $26(70.2)$ & $11(29.7)$ & \\
\hline
\end{tabular}

*Significant $p$-values

Table 4 Correlation of clinicopathological characteristics with EBV/HPV positivity

\begin{tabular}{llll}
\hline Stages & HPV $\mathbf{\pm} / \mathrm{EBV} \pm(\%)$ & HPV $+/ E B V+(\%)$ & p-value \\
\hline PT1 & $16(29)$ & $2(3.6)$ & $\mathrm{p}=0.035^{*}$ \\
pT2 & $14(25.4)$ & $5(9)$ & \\
PT3 & $4(7.2)$ & $5(9)$ & \\
pT4 & $4(7.2)$ & $5(9)$ & \\
Total & $38(69)$ & $17(30.9)$ & \\
\hline
\end{tabular}

*Significant $p$-values

\section{Discussion}

Oncovirus infections are one of the main underlying sources for the onset and progression of infection-related cancer cases $[54,55]$. Viral infections are primarily dominant in developing countries; however, their occurrence cannot be overlooked in developed countries $[56,57]$.

High-risk HPVs and EBV are important etiological factors in human HN cancer, especially oral; as approximately $35 \%$ and $55 \%$ of oral cancers are positive for these viruses, respectively [48]. Moreover, several studies have indicated the co-presence of high-risk HPVs and EBV in human oral cancer [42, 48, 58-60] and hence this study aims to investigate the co-presence of high-risk HPVs and EBV in tissue specimens of HN cancer from Bosnia in relation to tumor phenotype. Both EBV and high-risk HPVs share various features in terms of infection of oral epithelial tissue; these viruses infect and lead to epithelial tissue differentiation from the upper aero-digestive tract which stimulates both prolific and lytic phases of HPV's and EBV's life cycle, respectively [61].

Approximately $38 \%$ of virus-related cancers, display presence of EBV in addition to high-risk HPVs [55]; especially types 16,18 , and 33 , which cumulatively infect $80-90 \%$ of the population worldwide [48]. Combined oncogenic effects of viral infections can lead to the onset and progression of cancer $[48,55]$.

In this study, EBV infection was observed in $69.3 \%$ of SCC cases by PCR analysis, of which $78.1 \%$ was found in the oral cavity, this is in concordance with other investigations in oral carcinomas where EBV infection was found to be higher than 50\% [58-60]. Jaloluli et al. [62, 63] examined the presence of EBV in eight different countries and showed an average of 55\% EBV prevalence (22\% in Yemen to $80 \%$ in the UK), suggesting EBV infection in oral cancer to be dependent on geographical region $[64,65]$.

On the other hand, we found that $45.3 \%$ of oral cancer cases are positive for high-risk HPVs, similar to previous studies [60]. The most frequent high-risk HPV types in Bosnian SCC patients are (HPVs-16, -18, -45 and -58) (21.4\%, $56.1 \%, 27.5 \%$ and $47.9 \%$, respectively. It is important to highlight that, Iljazović et al. [66] reported that the most frequent HPVs in cervical cancer in Bosnian women are types $16,18,45,33,51$ and 31 , respectively. However, there are no studies to date regarding the presence of HPVs in HN cancer, including oral, in Bosnia.

Regarding the co-incidence of HPV and EBV in oral carcinoma, our study showed a higher rate of infection (37.5\%) in comparison with other HN carcinomas (larynx and pharynx) including the skin and cervix $(<5 \%)$. Furthermore, HPV-18 accounted for the majority of oral carcinomas (45.3\%) compared with other HN carcinomas (larynx and pharynx) including the skin and cervix carcinomas $(<3 \%)$, which have been previously reported [67]. While, a study by Fregonesi et al. found HPV 16/18 positivity in $40 \%$ of Brazilian oral premalignant lesions [68]; Shroyer et al. found 17\% of HPV16/18 positivity in samples from Colorado of the USA [69]. Our study showed that $12.5 \%$ of our samples are positive for HPV16/18, which is in accordance with a study by Agrawal et al. where they found $10 \%$ HPV16/18 positivity in oral epithelial dysplasia in India [70].

As reported earlier, high-risk HPV inhibits changes in the EBV genome in normal oral cells and induces EBV lytic recurrence in differentiating epithelial cells, indicating co-infection with HPV might enhance EBVdirected pathogenesis in the oral cavity [61]. Several studies showed co-infection by high-risk HPVs and EBV in roughly $38 \%$ of human nasopharyngeal carcinomas [58, 71, 72]; our study showed comparable results where 
oral cancer cases were co-infected by high-risk HPVs and EBV in $37.5 \%$ of the cases. Moreover, we herein found significant association between the co-presence of EBV and high-risk HPVs in SCC. These results are in agreement with a study performed by Jiang et al. [73] where significant correlation was found between EBV and HPV in oropharyngeal cancers [73]. Although, several investigations have been conducted, nevertheless, the exact role of EBV and HPV interaction in human carcinogenesis has not clearly been identified [74]. While, Makielski et al. [61] suggested that HPV infection in the oral cavity may enhance the capacity of epithelial cells to support EBV life cycle, which can further enhance EBV-mediated pathogenesis in the oral cavity. On the other hand, a study by Guidry and Scott [75] denoted that co-infection by HPV and EBV might escalate EBV persistence either via latency or increased viral replication and by increasing HPV oncogene expression. In this regard, it is well established that high-risk HPV infection alone is not enough to stimulate neoplastic transformation of normal human epithelial cells [45]; thus, HPV could interact with other oncoviruses such as EBV to induce cell transform of different types of human epithelial cells including oral [42, 76], indicating the importance of further genetic changes or co-infection with other oncoviruses. Previous research by our group showed that E6/E7 of HPV type 16 along with ErbB-2, which is upregulated in $30 \%$ of oral carcinomas [77], induce cellular transformation of oral epithelial cells [46] via $\beta$-catenin tyrosine phosphorylation by pp60 (c-Src) kinase activation $[46,78]$. On the other hand, EBV can infect and immortalize human primary epithelial cells in vitro $[45,79]$. Among several known EBV genes, it was reported that LMP1 and BARF1 can induce malignant transformation in rodent fibroblasts $[80,81]$, indicating their role as viral oncogenes.

Mellin et al. [82] found a significant association between TNM staging and HPV positivity. Our results are in accordance with this study, by showing that highrisk HPV presence is correlated with poorly differentiated SCC $(p=0.02)$, tumor stage $(p<0.001)$ as well as more advanced $\mathrm{pN}$ stage $(\mathrm{p}=0.045)$. Moreover, we herein demonstrate for the first time that the co-presence of EBV and high-risk HPVs is associated with advanced tumor stage $(\mathrm{p}=0.035)$; suggesting that high-risk HPVs and EBV oncoproteins can cooperate in the initiation and/or progression of human oral cancer. Therefore, coinfections with high-risk HPV subtypes and EBV can enhance the onset and progression of oral or oropharyngeal tumors [58]. Thus, blocking of EBV lytic replication due to induction of HPV may lead to EBV latency which has been linked with invasive phenotype and deferred differentiation in oral keratinocytes latently infected with EBV [83, 84]. Therefore, HPV-induced EBV latency can be associated with long-term EBV oncogene expression that could contribute in the progression of $\mathrm{HPV}+$ oral SCC [85]. In this context, our group, previously pointed out the possible cooperative role of LMP1 and/or EBNA1 genes of EBV as well as E5 and E6/E7 genes of high-risk HPVs in the initiation and/or progression of different types of human carcinomas via the EMT event [47]. In the present study, EBV +/HPV + showed positive correlation with advanced tumor stage $(\mathrm{p}=0.035)$, however, no positive association was found with tumor grade $(\mathrm{p}=0.4)$; thus, lack of association between the co-presence of these oncoviruses and tumor grade can be due to the relatively small sample size.

\section{Conclusions}

In this study, we explored, for the first time, the co-presence of EBV and high-risk HPVs in human HN cancer from Bosnia. Our data revealed that the most frequent high-risk HPVs in HN cancers in the Bosnian population are HPV types 18, 58, 45 and 16, respectively. Moreover, we report that EBV and high-risk HPVs are co-present in $34.7 \%$ of our HN cancer samples. More significantly, our investigation pointed out that the co-presence of EBV and high-risk HPVs is strongly associated with advanced tumor stage of HN cancer, which suggests that these oncoviruses can cooperate in the progression of this cancer. Thus, we believe that more investigations with a larger number of samples are necessary to confirm these findings which could be very important in the prevention of HN cancer as well as other EBV and HPVs associated cancers via selecting the right vaccine for specific populations. Meanwhile, mechanistic studies are crucial to elucidate the cooperation role of EBV and high-risk HPVs in the initiation and/or progression of human $\mathrm{HN}$ cancer.

\section{Supplementary information}

Supplementary information accompanies this paper at https://doi. org/10.1186/s12935-020-01348-y.

Additional file 1: Figure S1. Representative PCR reactions for HPV-subtypes in 15 different HNSCC patients.

Additional file 2: Figure S2. Representative PCR reactions for EBV (LMP1) in 15 different HNSCC patients.

\section{Abbreviations}

DNA: Deoxyribonucleic acid; EBV: Epstein-Barr virus; EBNA: EBV-encoded nuclear antigens; HPV: Human papilloma virus; HNSCC: Head and neck squamous cell carcinoma; IHC: Immunohistochemistry; LMP: Latent membrane protein; PCR: Polymerase chain reaction; TMA: Tissue microarray.

\section{Acknowledgements}

The authors would like to thank Mrs. A. Kassab for her critical reading of the manuscript. The publication of this article was funded by the Qatar National Library. 


\section{Authors' contributions}

Conceptualization, AEA, SV and HA; Methodology, AJ, IG, AY, TA and SV; validation, AJ, IG, and SV; Formal analysis, AJ, IG, FS, HA and SV; Writing —original draft preparation, IG; Writing - review and editing, IG, SV, MIM, HA and AEA; Supervision, HA, AEA, GB and SV. Funding acquisition, HA and AEA. All authors read and approved the final manuscript.

\section{Funding}

This work was supported by grants from Qatar University: GCC-2017-

002 QU/KU, QUCG-CMED-2018\2019-3, QUCG-CMED-20/21-2 and

QUHI-CMED-19/20-1.

\section{Availability of data and materials}

All data generated or analyzed during this study are included in this published article (and its addiitonal files).

\section{Ethics approval and consent to participate}

This study was approved by Qatar University IBC and IRB committees (Numbers: QU-IBC-2018/064 and APP-16/05/2018/GCC). On the other hand, use of anonymous samples was approved by the Department of Pathology, Clinical Center, University of Sarajevo.

\section{Consent for publication}

Not applicable.

\section{Competing interests}

The authors declare that they have no competing interests.

\section{Author details}

${ }^{1}$ College of Medicine, QU Health, Qatar University, P. O. Box 2713, Doha, Qatar. ${ }^{2}$ Department of Pathology, Clinical Center, University of Sarajevo, 71000 Sarajevo, Bosnia and Herzegovina. ${ }^{3}$ Segal Cancer Center/Lady Davis Institute for Medical Research, JGH/McGill University, Montreal, QC, Canada. ${ }^{4}$ Biomedical Research Centre, Qatar University, P. O. Box 2713, Doha, Qatar.

\section{Received: 11 November 2019 Accepted: 15 June 2020}

Published online: 03 August 2020

\section{References}

1. Pai SI, Westra WH. Molecular pathology of head and neck cancer: implications for diagnosis, prognosis, and treatment. Annu Rev Pathol. 2009:4:49-70

2. Fan C-Y. Epigenetic alterations in head and neck cancer: prevalence, clinical significance, and implications. Curr Oncol Rep. 2004:6(2):152-61.

3. Garfinkel L. Perspectives on cancer prevention. CA Cancer J Clin. 1995:45(1):5-7.

4. Adeyemi BF, Adekunle LV, Kolude BM, Akang EEU, Lawoyin JO. Head and neck cancer - a clinicopathological study in a tertiary care center. J Natl Med Assoc. 2008;100(6):690-7.

5. Gupta N, Gupta R, Acharya AK, Patthi B, Goud V, Reddy S, et al. Changing trends in oral cancer-a global scenario. Nepal J Epidemiol. 2016;6(4):613-9.

6. Warnakulasuriya S. Global epidemiology of oral and oropharyngeal cancer. Oral Oncol. 2009;45(4):309-16.

7. Venuti ABG, Rizzo C, Mafera B, Rahimi S, Vigili M. Presence of HPV in head and neck tumours: high prevalence in tonsillar localization. J Exp Clin Cancer Res. 2004;23:561-6.

8. Daling JRMM, Johnson LG, Schwartz SM, Shera KA, Wurscher MA, Carter JJ, Porter PL, Galloway DA, McDougall JK. Human papillomavirus, smoking, and sexual practices in the etiology of anal cancer. Cancer. 2004; 101:270-80.

9. Ragin C, Taioli E. Survival of squamous cell carcinoma of the head and neck in relation to human papillomavirus infection: review and metaanalysis. Int J Cancer. 2007;121:1813-20.

10. Smith JS, Lindsay L, Hoots B, Keys J, Franceschi S, Winer R, et al. Human papillomavirus type distribution in invasive cervical cancer and high-grade cervical lesions: a meta-analysis update. Int J Cancer. 2007;121(3):621-32
11. Stanley MA. Genital human papillomavirus infections: current and prospective therapies. J Gen Virol. 2012;93(4):681-91.

12. Castellsagué XDM, de Sanjosé S, Muñoz N, Herrero R, Franceschi S, Peeling RW, Ashley R, Smith JS, Snijders PJ, et al. International Agency for Research on Cancer Multicenter Cervical Cancer Study Group Worldwide human papillomavirus etiology of cervical adenocarcinoma and its cofactors: implications for screening and prevention. J Natl Cancer Inst. 2006;98:303-15.

13. Bernard $\mathrm{H}-\mathrm{U}$. The clinical importance of the nomenclature, evolution and taxonomy of human papillomaviruses. J Clin Virol. 2005;32:1-6.

14. de Villiers E-M, Fauquet $\mathrm{C}$, Broker TR, Bernard H-U, zur Hausen H. Classification of papillomaviruses. Virology. 2004;324(1):17-27.

15. Schwartz SMDJ, Shera KA, Madeleine MM, McKnight B, Galloway DA, Porter PL, McDougall JK. Human papillomavirus and prognosis of invasive cervical cancer: a population-based study. J Clin Oncol. 2001;19:1906-15.

16. Graflund MSB, Sigurdardóttir S, Karlsson M. HPV-DNA, vascular space invasion, and their impact on the clinical outcome in early-stage cervical carcinomas. Int J Gynecol Cancer. 2004;14:896-902.

17. Zuna R, Allen RA, Moore WE, Mattu R, Dunn ST. Comparison of human papillomavirus genotypes in high-grade squamous intraepithelial lesions and invasive cervical carcinoma: evidence for differences in biologic potential of precursor lesions. Mod Pathol. 2004;17:1314-22.

18. Begum S, Gillison ML, Ansari-Lari MA, Shah K, Westra WH. Detection of human papillomavirus in cervical lymph nodes: a highly effective strategy for localizing site of tumor origin. Clin Cancer Res. 2003;9:6469-75.

19. Umudum H, Rezanko T, Dag F, DogrulukT. Human papillomavirus genome detection by in situ hybridization in fine-needle aspirates of metastatic lesions from head and neck squamous cell carcinomas. Cancer. 2005;105:171-7.

20. Varnai A, Bollmann M, Griefingholt H, Speich N, Schmitt C, Bollmann R, Decker D. HPV in anal squamous cell carcinoma and anal intraepithelial neoplasia (AIN). Impact of HPV analysis of anal lesions on diagnosis and prognosis. Int J Colorectal Dis. 2006;2:135-42.

21. Yasmeen A, Bismar TA, Kandouz M, Foulkes WD, Desprez P-Y, Al Moustafa A-E. E6/E7 of HPV type 16 promotes cell invasion and metastasis of human breast cancer cells. Cell Cycle. 2007;6(16):2038-42.

22. Niedobitek G, Meru N, Delecluse HJ. Epstein-Barr virus infection and human malignancies. Int J Exp Pathol. 2001;82(3):149-70.

23. Young LS, Rickinson AB. Epstein-Barr virus: 40 years on. Nat Rev Cancer. 2004:4(10):757-68.

24. Middeldorp JM, Brink AA, van den Brule AJ, Meijer CJ. Pathogenic roles for Epstein-Barr virus (EBV) gene products in EBV-associated proliferative disorders. Crit Rev Oncol Hematol. 2003;45(1):1-36.

25. Murata T, Tsurumi T. Switching of EBV cycles between latent and lytic states. Rev Med Virol. 2014;24(3):142-53.

26. Cyprian FS, Al-Farsi HF, Vranic S, Akhtar S, Al Moustafa A-E. Epstein-Barr virus and human papillomaviruses interactions and their roles in the initiation of epithelial-mesenchymal transition and cancer progression. Front Oncol. 2018:8:111

27. Banko AV, Lazarevic IB, Folic MM, Djukic VB, Cirkovic AM, Karalic DZ, et al. Characterization of the variability of Epstein-Barr virus genes in nasopharyngeal biopsies: potential predictors for carcinoma progression. PLOS ONE. 2016:11(4):e0153498.

28. Shibata D, Weiss LM. Epstein-Barr virus-associated gastric adenocarcinoma. Am J Pathol. 1992:140(4):769-74.

29. Jácome AA, Lima EM, Kazzi Al, Chaves GF, Mendonça DC, Maciel MM, et al. Epstein-Barr virus-positive gastric cancer: a distinct molecular subtype of the disease? Rev Soc Bras Med Trop. 2016;49(2):150-7.

30. Hu H, Luo M-L, Desmedt C, Nabavi S, Yadegarynia S, Hong A, et al. Epstein-Barr virus infection of mammary epithelial cells promotes malignant transformation. EBioMedicine. 2016;9:148-60.

31. Al Moustafa A-E, Al-Antary N, Aboulkassim T, Akil N, Batist G, Yasmeen A Co-prevalence of Epstein-Barr virus and high-risk human papillomaviruses in Syrian women with breast cancer. Human Vacc Immunotherap. 2016;12(7):1936-9.

32. Al-Thawadi H, Ghabreau L, Aboulkassim T, Yasmeen A, Vranic S, Batist G, et al. Co-incidence of Epstein-Barr virus and high-risk human papillomaviruses in cervical cancer of syrian women. Front Oncol. 2018;8:250.

33. Landers RJ, O'Leary JJ, Crowley M, Healy I, Annis P, Burke L, et al. EpsteinBarr virus in normal, pre-malignant, and malignant lesions of the uterine cervix. J Clin Pathol. 1993:46(10):931-5. 
34. Wong KY, Collins RJ, Srivastava G, Pittaluga S, Cheung AN, Wong LC. Epstein-Barr virus in carcinoma of the cervix. Int J Gynecol Pathol. 1993;12(3):224-7.

35. Morales-Sánchez A, Molina-Muñoz T, Martínez-López JL, Hernández-Sancén P, Mantilla A, Leal YA, et al. No association between Epstein-Barr virus and mouse mammary tumor virus with breast cancer in Mexican women. Sci Rep. 2013;3:2970.

36. Glaser SL, Hsu JL, Gulley ML. Epstein-Barr virus and breast cancer: state of the evidence for viral carcinogenesis. Cancer Epidemiol Biomark Prev. 2004;13(5):688-97.

37. Chu PG, Chang KL, Chen YY, Chen WG, Weiss LM. No significant association of Epstein-Barr virus infection with invasive breast carcinoma. Am J Pathol. 2001;159(2):571-8.

38. Hilton DA, Brown $L$, Pringle JH, Nandha H. Absence of Epstein-Barr virus in carcinoma of the cervix. Cancer. 1993;72(6):1946-8.

39. Payne S, Kernohan NM, Walker F. Absence of in situ hybridization evidence for latent- or lytic-phase Epstein-Barr virus infection of preinvasive squamous lesions of the cervix. J Pathol. 1995;176(3):221-6.

40. Shimakage M, Horii K, Tempaku A, Kakudo K, Shirasaka T, Sasagawa T. Association of Epstein--Barr virus with oral cancers. Hum Pathol. 2002;33(6):608-14.

41. Horiuchi K, Mishima K, Ichijima K, Sugimura M, Ishida T, Kirita T. EpsteinBarr virus in the proliferative diseases of squamous epithelium in the oral cavity. Oral Surg Oral Med Oral Pathol Oral Radiol Endodontol. 1995;79(1):57-63.

42. Al Moustafa A-E, Chen D, Ghabreau L, Akil N. Association between human papillomavirus and Epstein-Barr virus infections in human oral carcinogenesis. Med Hypotheses. 2009;73(2):184-6.

43. Busson P, McCoy R, Sadler R, Gilligan K, Tursz T, Raab-Traub N. Consistent transcription of the Epstein-Barr virus LMP2 gene in nasopharyngeal carcinoma. J Virol. 1992;66(5):3257-62.

44. Hitt MM, Allday MJ, Hara T, Karran L, Jones MD, Busson P, et al. EBV gene expression in an NPC-related tumour. EMBO J. 1989;8(9):2639-51.

45. Al Moustafa A, Foulkes WD, Benlimame N, Wong A, Yen L, Bergeron J, Batist G, Alpert L, Alaoui-Jamali MA. E6/E7 proteins of HPV type 16 and ErbB-2 cooperate to induce neoplastic transformation of primary normal oral epithelial cells. Oncogene. 2004;23:350-8.

46. Al Moustafa A, Kassab A, Darnel A, Yasmeen A. High-risk HPV/ErbB-2 interaction on E-cadherin/catenin regulation in human carcinogenesis. Curr Pharm Des. 2008;14:2159-72.

47. Al Moustafa A-E. E5 and E6/E7 of high-risk HPVs cooperate to enhance cancer progression through EMT initiation. Cell Adh Migr. 2015;9(5):392-3.

48. Al Moustafa A-E, Cyprian FS, Al-Antary N, Yasmeen A. High-risk human papillomaviruses and Epstein-Barr virus presence and crosstalk in human oral carcinogenesis. In: Al Moustafa A-E, editor. Development of oral cancer: risk factors and prevention strategies. Cham: Springer International Publishing; 2017. p. 83-94.

49. Darnel AD, Wang D, Ghabreau L, Yasmeen A, Sami S, Akil N, et al. Correlation between the presence of high-risk human papillomaviruses and Id gene expression in Syrian women with cervical cancer. Clin Microbiol Infect. 2010;16(3):262-6.

50. Aboulkassim T, Yasmeen A, Akil N, Batist G, Al Moustafa A-E. Incidence of Epstein-Barr virus in Syrian women with breast cancer: a tissue microarray study. Hum Vacc Immunother. 2015;11(4):951-5.

51. Glenn WK, Heng B, Delprado W, lacopetta B, Whitaker NJ, Lawson JS. Epstein-Barr virus, human papillomavirus and mouse mammary tumour virus as multiple viruses in breast cancer. PloS ONE. 2012;7(11):e48788.

52. Fuessel Haws AL, He Q, Rady PL, Zhang L, Grady J, Hughes TK, et al. Nested PCR with the PGMY09/11 and GP5 +/6+ primer sets improves detection of HPV DNA in cervical samples. J Virol Methods. 2004;122(1):87-93.

53. Akil N, Yasmeen A, Kassab A, Ghabreau L, Darnel AD, Al Moustafa AE. High-risk human papillomavirus infections in breast cancer in Syrian women and their association with Id-1 expression: a tissue microarray study. Br J Cancer. 2008:99(3):404-7.

54. Weiss P. Tumour-inducing viruses. Br J Hosp Med. 2016;77(Sup 10):565-8.

55. Shi Y, Peng S-L, Yang L-F, Chen X, Tao Y-G, Cao Y. Co-infection of Epstein-Barr virus and human papillomavirus in human tumorigenesis. Chin J Cancer. 2016;35(1):16.
56. Antonsson A, Wilson LF, Kendall BJ, Bain CI, Whiteman DC, Neale RE. Cancers in Australia in 2010 attributable to infectious agents. Aust N Z J Public Health. 2015;39(5):446-51.

57. Parkin DM. The global health burden of infection-associated cancers in the year 2002. Int J Cancer. 2006;118(12):3030-44.

58. Drop B, Strycharz-Dudziak M, Kliszczewska E, Polz-Dacewicz M. Coinfection with Epstein-Barr Virus (EBV), human papilloma Virus (HPV) and polyoma BK virus (BKPyV) in laryngeal, oropharyngeal and oral cavity cancer. Int J Mol Sci. 2017;18(12):2752.

59. Polz-Gruszka D, Stec A, Dworzański J, Polz-Dacewicz M. EBV, HSV, CMV and HPV in laryngeal and oropharyngeal carcinoma in polish patients. Anticancer Res. 2015;35(3):1657-61.

60. Veitía D, Liuzzi J, Àvila M, De Guglielmo Z, Correnti M. Prevalence of HPV and EBV infection and their relationship with the p53 and PCNA expression in oral carcinoma patients. J Oral Res. 2017;4:86-91.

61. Makielski KR, Lee D, Lorenz LD, Nawandar DM, Chiu Y-F, Kenney SC, et al. Human papillomavirus promotes Epstein-Barr virus maintenance and lytic reactivation in immortalized oral keratinocytes. Virology. 2016;495:52-62.

62. Jalouli J, Jalouli MM, Sapkota D, Ibrahim SO, Larsson P-A, Sand L. Human papilloma virus, herpes simplex virus and Epstein-Barr virus in oral squamous cell carcinoma from eight different countries. Anticancer Res. 2012;32(2):571-80.

63. Jalouli J, Ibrahim SO, Sapkota D, Jalouli MM, Vasstrand EN, Hirsch JM, et al. Presence of human papilloma virus, herpes simplex virus and Epstein-Barr virus DNA in oral biopsies from Sudanese patients with regard to toombak use. J Oral Pathol Med. 2010;39(8):599-604.

64. Sand L, Wallstrom M, Hirsch JM. Smokeless tobacco, viruses and oral cancer. Oral Health Dent Manag. 2014;13(2):372-8.

65. Kis A, Fehér E, Gáll T, Tar I, Boda R, Tóth ED, et al. Epstein-Barr virus prevalence in oral squamous cell cancer and in potentially malignant oral disorders in an eastern Hungarian population. Eur J Oral Sci. 2009;117(5):536-40.

66. Iljazović E, Mena M, Tous S, Alemany L, Omeragić F, Sadiković A, et al. Human papillomavirus genotype distribution in invasive cervical cancer in Bosnia and Herzegovina. Cancer Epidemiol. 2014;38(5):504-10.

67. Kreimer AR, Clifford GM, Boyle P, Franceschi S. Human papillomavirus types in head and neck squamous cell carcinomas worldwide: a systematic review. Cancer Epidemiol Biomark Prev. 2005;14(2):467-75.

68. Gabrielli Fregonesi PA, Teresa DB, Duarte RA, Neto CB, de Oliveira MRB, Soares CP. p16INK4A immunohistochemical overexpression in premalignant and malignant oral lesions infected with human papillomavirus. J Histochem Cytochem. 2003;51 (10):1291-7.

69. Shroyer KR, Greer RO. Detection of human papillomavirus DNA by in situ DNA hybridization and polymerase chain reaction in premalignant and malignant oral lesions. Oral Surg Oral Med Oral Pathol. 1991;71(6):708-13.

70. Agrawal GP, Joshi PS, Agrawal A. Role of HPV-16 in pathogenesis of oral epithelial dysplasia and oral squamous cell carcinoma and correlation of p16INK4A expression in HPV-16 positive cases: an immunohistochemical study. ISRN Pathol. 2013;2013:1-7.

71. Tyan YS, Liu ST, Ong WR, Chen ML, Shu CH, Chang YS. Detection of Epstein-Barr virus and human papillomavirus in head and neck tumors. J Clin Microbiol. 1993;31(1):53-6.

72. Tung YC, Lin KH, Chu PY, Hsu CC, Kuo WR. Detection of human papilloma virus and Epstein-Barr virus DNA in nasopharyngeal carcinoma by polymerase chain reaction. Kaohsiung J Med Sci. 1999;15(5):256-62.

73. Jiang R, Ekshyyan O, Moore-Medlin T, Rong X, Nathan S, Gu X, et al. Association between human papilloma virus/Epstein-Barr virus coinfection and oral carcinogenesis. J Oral Pathol Med. 2015;44(1):28-36.

74. Shi Y, Peng S-L, Yang L-F, Chen X, Tao Y-G, Cao Y. Co-infection of Epstein-Barr virus and human papillomavirus in human tumorigenesis. Chin J Cancer. 2016;35:16.

75. Guidry JT, Scott RS. The interaction between human papillomavirus and other viruses. Virus Res. 2017;231:139-47.

76. Pattle SB, Farrell PJ. The role of Epstein-Barr virus in cancer. Expert opinion on biological therapy. 2006;6(11):1193-205.

77. Xia W, Lau YK, Zhang HZ, Liu AR, Li L, Kiyokawa N, et al. Strong correlation between c-erbB-2 overexpression and overall survival of patients with oral squamous cell carcinoma. Clin Cancer Res. 1997;3(1):3-9. 
78. Yasmeen A, Hosein AN, Yu Q, Al Moustafa A-E. Critical role for D-type cyclins in cellular transformation induced by E6/E7 of human papillomavirus type 16 and E6/E7/ErbB-2 cooperation. Cancer Sci. 2007;98(7):973-7.

79. Wei MX, de Turenne-Tessier M, Decaussin G, Benet G, Ooka T. Establishment of a monkey kidney epithelial cell line with the BARF1 open reading frame from Epstein-Barr Virus. Oncogene. 1997;14(25):3073-81.

80. Wang D, Liebowitz D, Kieff E. An EBV membrane protein expressed in immortalized lymphocytes transforms established rodent cells. Cell. 1985:43(3):831-40.

81. Wei MX, Ooka T. A transforming function of the BARF1 gene encoded by Epstein-Barr virus. EMBO J. 1989:8(10):2897-903.

82. Mellin H, Friesland S, Lewensohn R, Dalianis T, Munck-Wikland E. Human papillomavirus (HPV) DNA in tonsillar cancer: clinical correlates, risk of relapse, and survival. Int J Cancer. 2000;89(3):300-4.

83. Birdwell CE, Queen KJ, Kilgore PCSR, Rollyson P, Trutschl M, Cvek U, et al. Genome-wide DNA methylation as an epigenetic consequence of Epstein-Barr virus infection of immortalized keratinocytes. J Virol. 2014;88(19):11442-58.

84. Birdwell CE, Prasai K, Dykes S, Jia Y, Munroe TGC, Bienkowska-Haba M, et al. Epstein-Barr virus stably confers an invasive phenotype to epithelial cells through reprogramming of the WNT pathway. Oncotarget. 2018;9(12):10417-35

85. Guidry JT, Myers JE, Bienkowska-Haba M, Songock WK, Ma X, Shi M, et al. Inhibition of Epstein-Barr virus replication in human papillomavirusimmortalized keratinocytes. J Virol. 2019:93(2):e01216-8.

\section{Publisher's Note}

Springer Nature remains neutral with regard to jurisdictional claims in published maps and institutional affiliations.
Ready to submit your research? Choose BMC and benefit from:

- fast, convenient online submission

- thorough peer review by experienced researchers in your field

- rapid publication on acceptance

- support for research data, including large and complex data types

- gold Open Access which fosters wider collaboration and increased citations

- maximum visibility for your research: over $100 \mathrm{M}$ website views per year

At BMC, research is always in progress.

Learn more biomedcentral.com/submissions 